Acta vet. scand. $1976,17,43-62$.

From the Department of Obstetrics and Gynaecology

and the Department of Clinical Biochemistry,

Veterinary College, Stockholm, Sweden.

\title{
FERTILITY OF DEEP FROZEN BOAR SPERMATOZOA
}

\section{INFLUENGE OF THAWING DILUENTS AND OF BOARS*}

\author{
By
}

K. Larsson and S. Einarsson

\begin{abstract}
LARSSON, K. and S. EINARSSON: Fertility of deep frozen boar spermatozoa. Influence of thawing diluents and of boars. Acta vet. scand. 1976, 17, 43-62. - In the present investigation the results of two insemination trials with deep frozen boar spermatozoa are presented. The aim of the trials was to study the effect of different thawing diluents and to compare the fertility of deep frozen spermatozoa from four boars. The trials utilized a total of 139 gilts.

The thawing diluents used were boar seminal plasma, protein free seminal plasma, the thawing diluent OLEP and isotonic glucose solution. The composition of OLEP was based on physical and biochemical analyses of boar seminal plasma. The electrolyte levels, pH and osmotic pressure of OLEP are similar to those of boar seminal plasma.

From the results it is evident that thawing in boar seminal plasma, protein free seminal plasma and OLEP yielded equal results. Thawing in isotonic glucose solution yielded significantly poorer results concerning percentage of fertilized ova $24-48 \mathrm{hrs}$. after insemination and almost significantly poorer fertility results four weeks after insemination.

The possible effects of the thawing diluents are discussed. With the freezing procedure applied, electrolyte levels, $\mathrm{pH}$ and osmotic pressure seem to be factors of importance for the survival of the frozen and thawed spermatozoa and for the maintenance of their fertilizing capacity.

Almost significant differences were found in fertility of spermatozoa from different boars. These differences were reflected in pregnancy rates as well as ratio of foetuses to c. l. in pregnant gilts. The differences were found to be independent of thawing diluent.

The variation seems to be caused by differences in resistance of the spermatozoa to the freezing and thawing procedure. The need for laboratory methods for selection of boars with spermatozoa of good freezability is stressed.
\end{abstract}

deep frozen boar spermatozoa; fertility; thawing diluents; freezability.

* This study was supported by grants from Svensk Husdjursskötsel, Hållsta and the Swedish Council for Forestry and Agricultural Research. 
During the years 1971-1973 several methods for deep freezing of boar spermatozoa with maintained fertility were presented (Crabo \& Einarsson 1971, Graham et al. 1971 a, b, Pursel \& Johnson $1971 \mathrm{a}, \mathrm{b}$, Richter \& Liedicke 1972, Paquignon \& du Mesnil $d u$ Buisson 1973). Freezing by the pellet method (Nagase \& Niwa 1964) was common for the methods described while composition of diluents and processing of semen varied greatly.

Thawing was performed in thawing diluents (Crabo \& Einarsson, Richter \& Liedicke, Paquignon \& du Mesnil du Buisson) or on preheated teflon pan without further dilution (Graham et al. $1971 \mathrm{a}, \mathrm{b}$, Pursel \& Johnson $1971 \mathrm{a}, \mathrm{b})$.

Since then a number of modifications of the original methods have been described. These modifications include new thawing diluents (Einarsson et al. 1972, Boehnke et al. 1974, Romeny et al. 1974, Pursel \& Johnson 1975 a, Richter et al. 1975), different methods of thawing (Boehnke et al., Pursel \& Johnson 1974, 1975 a) and also a new method for freezing (Westendorf et al. 1975).

Frozen spermatozoa thawed in boar seminal plasma have yielded consistently good pregnancy rates and litter sizes (Crabo et al. 1972 a, Einarsson et al. 1973). Also thawing diluents containing seminal plasma as one ingredient have proven useful (Einarsson et al. 1974, Romeny 1974). From a practical point of view seminal plasma would be less useful than other diluents which would be easier to produce and handle.

In the papens cited fertility results have been presented regardless of the boars used. However, differences in freezability of spermatozoa from different boars have been indicated (Larsson $\&$ Einarsson $1975 \mathrm{~b}$ ). Therefore further investigations of the occurrence of differences in freezability of spermatozoa from various boars are necessary. It is also important to establish whether differences in freezability occur independently of modifications of the freezing methods.

The aims of the present investigation were to:

1. Investigate the importance of some major characteristics of boar seminal plasma for the maintenance of the fertilizing ability of deep frozen boar spermatozoa after thawing.

2. Utilize the information obtained for the preparation of a new synthetic thawing diluent for deep frozen boar spermatozoa and to evaluate its function in a fertility test. 
3. Compare the fertility of frozen-thawed spermatozoa from different boars.

Parts of the results have previously been reported (Larsson \& Einarsson 1975 a, b).

\section{MATERIAL AND METHODS}

This study was carried out in two trials from January 1974 until June 1975. During this period a total of 139 crossbred (Sw. Landrace $\times$ Sw. Yorkshire) gilts were inseminated. Seventy gilts were inseminated in trial I and 69 were inseminated in trial II.

In trial I one Swedish Landrace (350) and one Swedish Yorkshire boar (388) were utilized as sources of semen. In trial II one Swedish Landrace boar (172) and two Swedish Yorkshire boars supplied the semen $(388,1164)$.

Trial I. A comparison of the fertility of deep frozen boar spermatozoa thawed in one of three thawing diluents: boar seminal plasma (A), protein free boar seminal plasma (B), or isotonic glucose solution (D).

Trial IIa. A comparison of the fertility of deep frozen boar spermatozoa thawed in boar seminal plasma (A) or in the thawing diluent OLEP (C).

\section{Experimental procedure}

A summary of the utilization of the boars and the gilts in the different experiments is given in Table 1. Four gilts were excluded from trials I and IIa due to abnormalities of their genital tracts found at post-mortem examination. One gilt was excluded from trial IIb due to heavy backflow of semen during and immediately after insemination.

In trial I each ejaculate was split for thawing in at least two of the diluents used. Equal numbers of gilts were inseminated with spermatozoa from each of two boars after thawing in each of the diluents used.

Trial IIa was performed as a strict split ejaculate trial. From each ejaculate utilized one gilt was inseminated with spermatozoa thawed in diluent $A$ and one gilt was inseminated with spermatozoa thawed in diluent $\mathrm{C}$. 
T a ble 1. Distribution of gilts and utilization of boars in trial $I$, trial IIa and trial IIb.

\begin{tabular}{|c|c|c|c|c|c|}
\hline \multirow[b]{2}{*}{ Boar } & \multirow[b]{2}{*}{$\begin{array}{l}\text { Thawing } \\
\text { diluent }\end{array}$} & \multicolumn{4}{|c|}{ Number of gilts } \\
\hline & & $\begin{array}{l}\text { insemi- } \\
\text { nated }\end{array}$ & $\begin{array}{c}\text { designated } \\
\text { for slaughter } \\
\mathbf{2 4 - 4 8} \mathrm{hrs} . \\
\text { after insemi- } \\
\text { nation }\end{array}$ & $\begin{array}{c}\text { designated } \\
\text { for slaughter } \\
\text { four weeks } \\
\text { after insemi- } \\
\text { nation }\end{array}$ & excluded \\
\hline \multicolumn{6}{|c|}{ Trial I } \\
\hline 388 & $\mathbf{A}$ & 15 & 4 & 11 & 1 \\
\hline 388 & B & 10 & 2 & 8 & \\
\hline 388 & $\bar{D}$ & 10 & 5 & 5 & \\
\hline 350 & $\mathbf{A}$ & 15 & 4 & 11 & \\
\hline 350 & B & 10 & 2 & 8 & \\
\hline 350 & D & 10 & 4 & 6 & \\
\hline \multicolumn{6}{|c|}{ Trial I I a } \\
\hline 388 & A & 10 & & 10 & 1 \\
\hline 388 & C & 10 & & 10 & \\
\hline 172 & $\mathbf{A}$ & 10 & & 10 & \\
\hline 172 & $\mathrm{C}$ & 10 & & 10 & \\
\hline 1164 & $\mathbf{A}$ & 10 & & 10 & \\
\hline 1164 & C & 10 & & 10 & 2 \\
\hline \multicolumn{6}{|c|}{ Trial I I b } \\
\hline 388 & C & 4 & 3 & & 1 \\
\hline 172 & C & 8 & 2 & & \\
\hline 1164 & C. & 3 & 3 & & \\
\hline
\end{tabular}

In addition to trial IIa nine gilts were inseminated with spermatozoa thawed in diluent $\mathrm{C}$ and slaughtered 24-48 hrs. later (trial IIb). For these inseminations portions of ejaculates previously utilized in trial IIa were used.

No control of the frozen-thawed semen was performed before insemination i.e. the quality of the frozen-thawed semen was unknown at the time of insemination.

\section{Boars used}

The fertility of the boars was previously lested in natural service and/or by artificial insemination with fresh semen and was found to be good. The semen quality of the boars was controlled before and during the trials and judged as normal according to the classification of Holst (1949) and Bane (1961). 


\section{Collection and processing of semen}

Semen was collected and frozen once a week. Only the spermrich fraction of the ejaculates was utilized for freezing. In trial I an artificial vagina and in trial II the gloved hand technique were used for collection of semen. Within 20 min. after collection the motility (the percentage of motile spermatozoa) of the native semen was estimated. Ejaculates with less than $70 \%$ motile spermatozoa were discarded. The sperm concentration as estimated with an EEL absorptiometer varied between 0.9 and $1.4 \times$ $10^{9}$ spermatozoa per $\mathrm{ml}$ in the utilized fractions. The semen was allowed to cool to room temperature $\left(20-24^{\circ} \mathrm{C}\right)$ over a $1 \mathrm{hr}$. perioid. After that, dilution 1:1 (v/v) was performed and the diluted semen was cooled in a waterbath in a refrigerator to $5^{\circ} \mathrm{C}$ over a 3 to $4 \mathrm{hr}$. period. Thereafter it was diluted once again 1:1 and immediately after the final dilution frozen in $0.1 \mathrm{ml}$ pellets on dry ice. The pellets were stored in liquid nitrogen until used. The diluent used was TESNaK-glucose-egg yolk buffer with the following composition: $70 \%$ TESNaK (Crabo et al. 1972b), $10 \%$ of a $5.5 \%$ isotonic glucose solution (ACO Stockholm) and $20 \%$ of hens egg yolk. The diluent was prepared according to Crabo et al. (1972a). At the second dilution the diluent was added with $5 \%$ glycerol, thus the final glycerol concentration was $2.5 \%$.

\section{Thawing diluents and thawing procedure}

The s e minal plas ma used was in most cases the centrifuged sperm-poor fractions of the ejaculates collected for freezing. Additionally in trial I seminal plasma from a boar with total testicular hypoplasia and from two bilaterally vasectomized boars was used. Limited tests did not indicate any influence on fertility related to the different origin of the seminal plasma. Consequently in presenting the results all inseminations performed with spermatozoa thawed in seminal plasma have been pooled.

The protein free seminal plas ma was prepared by using a Millipore $142 \mathrm{~mm}$ Laboratory Ultrafiltration system. This procedure excluded substances with molecular weights exceeding 1000. For this purpose seminal plasma from a boar with total testicular hypoplasia and the centrifuged sperm poor fractions mentioned above were utilized. 
T a b l e 2. Composition of OLEP.

\begin{tabular}{ll}
\hline Ingredient & Amount $(\mathrm{g})$ \\
\hline Fructose & 5.0 \\
Sodium pyruvate & 5.0 \\
CaCl$_{2}$ & 0.06 \\
$\mathrm{MgCl}_{2}$ & 0.865 \\
$\mathrm{KCl}$ & 1.2 \\
$\mathrm{NaCl}$ & 3.5 \\
$\mathrm{NaHCO}_{3}$ & 0.84 \\
\hline
\end{tabular}

After addition of benzylpenicillin seminal plasma and protein free seminal plasma were stored in $70 \mathrm{ml}$ portions at $-20^{\circ} \mathrm{C}$ until used.

When seminal plasma of the centrifuged sperm-poor fractions was used as thawing diluent the spermatozoa and the seminal plasma derived from the same boar.

Random samples of seminal plasma and of protein free seminal plasma used for thawing in trial I were analysed for concentrations of sodium, potassium, chloride, calcium, magnesium and proteins. Furthermore $\mathrm{pH}$ and osmotic pressure were determined. The methods used were previously described by Einarsson (1971).

T a b l e 3. Results of biochemical analyses of seminal plasma from six ejaculates of three boars before and after ultrafiltration. Calculated values of OLEP are given as comparison.

\begin{tabular}{lccr}
\hline $\begin{array}{l}\text { Electrolyte } \\
\text { (meq/l) }\end{array}$ & $\begin{array}{c}\text { Seminal plasma } \\
(\text { mean } \pm \mathrm{s})\end{array}$ & $\begin{array}{c}\text { Ultrafiltrate } \\
(\text { mean } \pm \mathrm{s})\end{array}$ & OLEP \\
\hline Sodium & $117.8 \pm 11.2$ & $116.7 \pm 10.3$ & 115 \\
Potassium & $15.0 \pm 0.8$ & $15.1 \pm 1.2$ & 15 \\
Chloride & $99.7 \pm 11.8$ & $100.0 \pm 11.3$ & 95 \\
Magnesium & $21.98 \pm 14.51$ & $13.97 \pm 5.73$ & 16.5 \\
Calcium & $1.22 \pm 0.33$ & $0.88 \pm 0.13$ & 1.0 \\
Total & & & \\
protein (mg/100 ml) & $3.0 \pm 1.6$ & 0 & - \\
pH & $7.87 \pm 0.26$ & $8.44 \pm 0.23$ & 7.8 \\
$\begin{array}{l}\text { Osmotic pressure } \\
\text { (mosm/l) }\end{array}$ & $319.0 \pm 3.8$ & $299.5 \pm 12.1$ & 328 \\
\hline
\end{tabular}

$\mathrm{Ph}$ and osmotic pressure are significantly different between whole seminal plasma and ultrafiltrate. 
As is evident from the results (Table 3) the levels of the electrolytes analysed were about equal in whole seminal plasma and in protein free seminal plasma. Neither were there any differences in the fertility aspects studied when using whole seminal plasma or protein free seminal plasma as thawing diluent (Tables 4, 5).

Utilizing these results a thawing diluent OLE $\mathrm{P}$ was prepared. Its electrolyte composition of $\mathrm{Na}, \mathrm{K}, \mathrm{Cl}, \mathrm{Ca}$, and $\mathrm{Mg}$ was almost identical with that of seminal plasma. Also its $\mathrm{pH}$ and osmotic pressure closely resembled those of seminal plasma (Table 3). OLEP was prepared under sterile conditions according to the description in Table 2. The ingredients were dissolved in sterile water to a volume of $1000 \mathrm{ml}$ and $\mathrm{pH}$ was adjusted with $\mathrm{NaOH}$ and $\mathrm{HCl}$ to 7.8. From preparation until usage the solution was stored in a refrigerator. Maximum storage time was one month.

The is otonic glucose solution used was a commercial $5.5 \%$ preparation (ACO Stockholm). This solution was stored under the same conditions as the OLEP solution.

Independent of $t h$ awing diluent, the $t h$ awing procedure was the same. Portions of approx. 30 pellets were transferred into the thawing diluent kept at $35^{\circ} \mathrm{C}$ in a hot water bath. The temperature in the thawing diluent varied between 30 and $35^{\circ} \mathrm{C}$ throughout the thawing procedure.

In the time between thawing and insemination prepared doses were kept at approx. $35^{\circ} \mathrm{C}$ in preheated vacuum flasks. The time from thawing to insemination varied from 5 to $20 \mathrm{~min}$. depending on, how many doses had to be prepared.

\section{Heat determination and insemination}

Heat control was performed once a day by an experienced stockman with the aid of vasectomized boars.

Before the trials were started an insemination scheme was settled for the use of semen and thawing diluents. Thus selection of gilts according to heat intensity was avoided. Inseminations were performed with rubber spiral-tip catheters according to Melrose \& O'Hagan (1961). All gilts were inseminated twice during their second or third observed heat period. The inseminations were performed during the afternoon of the first oestrus day and before noon on the following day with $16-20 \mathrm{hrs}$. intervals. 
Each insemination dose contained a total of $6 \times 10^{9}$ spermatozoa relying on the absorptiometric determination of initial sperm concentration and regardless of post-thawing motility. The spermatozoa were added to $70 \mathrm{ml}$ of thawing diluent, the average volume of the insemination doses being $90 \mathrm{ml}$.

\section{Fertility tests}

Twenty-one of the gilts in trial I and the nine gilts in trial IIb were slaughtered $24-48 \mathrm{hrs}$. after insemination in order to study the number of gilts with fertilized ova and the total percentage of fertilization occurring when using the different thawing diluents. Of the remaining gilts all gilts not returning to normal oestrus within 25 days after insemination were slaughtered four weeks after insemination.

The genital organs of these gilts were examined within $2 \mathrm{hrs}$. after slaughter. Numbers of corpora lutea (c.l.) and of foetuses were reconded. Gilts returning into normal oestrus within 25 days after insemination were considered non pregnant.

From the gilts slaughtered $24-48 \mathrm{hrs}$. after insemination the genital organs were removed immediately after stunning and bleeding. Within $45 \mathrm{~min}$. the genital organs were examined and the numbers of c.l. in the ovaries were recorded. The oviducts were cut into an isthmic and an ampullary part. These parts and the proximal $10 \mathrm{~cm}$ of the uterine horns were flushed with $5 \mathrm{ml}$ of physiological saline solution each. The flushing fluids were collected in separate tubes and examined for presence of ova under a dissection microscope at $15 \times$ magnification. Wet preparations of recovered ova were examined for cleavage under a phase contrast microscope with a maximum of $400 \times$ magnification. Numbers of recovered and cleaved ova were recorded. Only normally cleaved ova were judged as fertilized.

\section{STATISTICAL ANALYSES}

Statistical analyses were performed to test differences between thawing diluents in their effect on fertility of boars and also differences among boars within thawing diluents.

The methods used were chosen to be useful for small numbers of observations and for groups of different sizes. Where no statistical analyses were possible, conclusions were drawn from numerical differences. The methods used are described in statistical textbooks (c.f. Snedecor 1966, Lindström 1975). 
Differences in ratios of fertilized ova to recovered ova were tested with chi-square analyses.

In the following text "fertility" refers to both pregnancy rate and relative litter sizes (ratios of foetuses to corpora lutea) in pregnant gilts.

Differences in fertility four weeks after insemination were tested by Wilcoxon's rank sum test for unpaired measurements. The value of the ratio of foetuses to corpora lutea (c.l.) was used as a fertility index for each gilt. Non-pregnant gilts were given the value of zero. This procedure admitted a comparison between groups including pregnancy rates (number of zeros) as well as ratios of foetuses to c.l. in pregnant gilts. Additionally differences in pregnancy rates were tested by Fisher's test for small numbers of observations.

In trial IIa the influence of boars on ratio of foetuses to c.l. in pregnant gilts was tested by a variance analysis for groups of unequal sizes.

The degree of significance is expressed as follows:

$$
\begin{aligned}
& 0.05>\mathrm{P}>0.01 \text { almost significant }{ }^{*} \\
& 0.01>\mathrm{P}>0.001 \text { significant }{ }^{\star} \text { * } \\
& \mathrm{P}<0.001 \text { highly significant }{ }^{\star \star *}
\end{aligned}
$$

\section{RESULTS}

\section{Comparison between thawing diluents}

Early fertility results

The fertility results of gilts slaughtered $24-48$ hrs. after insemination in trial $I$ are summarized in Table 4. The most striking effect of the thawing diluents on the fertility is the low percentage of fertilized ova following thawing in isotonic glucose solution. Only $9 \%$ of the recovered ova were fertilized when using this thawing diluent. This is highly significantly lower than the fertilization rate after thawing in the other diluents used. Also the percentage of gilts with fertilized ova is lower after thawing in isotonic glucose solution than with the other diluents although the differences are not statistically significant. There were no statistically significant differences between seminal plasma and protein free seminal plasma either in percentages of gilts with fertilized ova or in percentages of fertilized ova.

Out of the eight normal gilts inseminated in trial IIb with spermatozoa thawed in OLEP, seven had fertilized ova, and the incidence of fertilization in recovered ova from all slaughtered gilts was $42 \%$. This is highly significantly superior to the results obtained after thawing in isotonic glucose solution in trial 
T a b l e 4. Number of gilts with fertilized ova, total numbers of corpora lutea (c.l.), of recovered ova and of fertilized ova in all gilts slaughtered $24-48 \mathrm{hrs}$. after insemination in trial I.

\begin{tabular}{|c|c|c|c|c|c|c|c|}
\hline \multirow{3}{*}{$\begin{array}{l}\text { Thawing } \\
\text { diluent }\end{array}$} & \multicolumn{3}{|c|}{ Number of gilts } & \multicolumn{3}{|c|}{ Total numbers of } & \multirow{3}{*}{$\begin{array}{l}\text { Percentage of } \\
\text { fert. ova out } \\
\text { of recovered }\end{array}$} \\
\hline & \multirow{2}{*}{$\begin{array}{c}\text { inse- } \\
\text { minated }\end{array}$} & \multicolumn{2}{|c|}{ with fert. ova } & \multirow[t]{2}{*}{ c.l. } & \multirow{2}{*}{$\begin{array}{l}\text { recovered } \\
\text { ova }\end{array}$} & \multirow{2}{*}{$\begin{array}{l}\text { fert. } \\
\text { ova }\end{array}$} & \\
\hline & & $\mathbf{n}$ & $\%$ & & & & \\
\hline $\mathbf{A}$ & 8 & 5 & 63 & 98 & 83 & 38 & 46 \\
\hline B & 4 & 4 & 100 & 45 & 33 & 22 & 63 \\
\hline D & 9 & 4 & 44 & 96 & 88 & 8 & $9^{\star \star \star}$ \\
\hline
\end{tabular}

The incidence of fertilized ova in group D is highly significantly different from the results after thawing in diluents $A$ and $B$. The difference in percentage of fertilized ova between A and B is not statistically significant.

I. On the other hand the results of thawing in OLEP were not significantly different from those obtained after thawing in seminal plasma or in protein free seminal plasma in trial $I$.

Fertility four weeks after insemination

The fertility results four weeks after insemination in trial I are given in Table 5 and the fertility results of trial IIa are given in Table 6.

From Table 5 it is evident that for both boars involved the fertility was almost significantly lower $(P<0.05)$ when thawing was performed in isotonic glucose solution than after thawing in seminal plasma or in protein free seminal plasma. The pregnancy rate for boar 350 was significantly and almost significantly lower after thawing in isotonic glucose solution than after thawing in seminal plasma and in protein free seminal plasma. Also for boar 388 the pregnancy rate was lowest after thawing in isotonic glucose solution although not significantly lower than after thawing in seminal plasma or in protein free seminal plasma.

In trial IIa (Table 6) the pregnancy rate of $75 \%$ following thawing in OLEP was almost significantly higher than the percentage of 20 after thawing in seminal plasma for boar 1164. However, the rank sum test of the difference in total fertility between the diluents for this boar did not indicate any significant difference $(P>0.05)$. The reason for this is that the gilts 
T a b l e 5. Numbers of normal gilts inseminated, number of gilts not returning into normal oestrus within 25 days post insemination (25d. N.R.), pregnancies and numbers of corpora lutea (c.l.) and foetuses and ratios of foetuses to c.l. in pregnant gilts slaughtered four weeks after insemination in trial $I$.

\begin{tabular}{|c|c|c|c|c|c|c|c|c|c|}
\hline \multirow[t]{3}{*}{ Boar } & \multirow{3}{*}{$\begin{array}{l}\text { Thawing } \\
\text { diluent }\end{array}$} & \multicolumn{4}{|c|}{ Number of gilts } & \multicolumn{2}{|c|}{ In pregnant gilts } & \multirow{2}{*}{\multicolumn{2}{|c|}{$\begin{array}{l}\text { Ratio of foetuses } \\
\text { to c.l. }\end{array}$}} \\
\hline & & \multirow{2}{*}{ ins. } & \multirow{2}{*}{$\begin{array}{l}25 d . \\
\text { N.R. }\end{array}$} & \multirow{2}{*}{ pregn. } & \multirow{2}{*}{$\%$} & \multirow{2}{*}{$\begin{array}{c}\text { mean } \\
\text { number } \\
\text { of } c .1 .\end{array}$} & \multirow{2}{*}{$\begin{array}{l}\text { mean } \\
\text { number of } \\
\text { foetuses }\end{array}$} & & \\
\hline & & & & & & & & range & mean \\
\hline 350 & $\mathbf{A}$ & 11 & 9 & 8 & 73 & 13.0 & 7.6 & $0.29 \longrightarrow 0.75$ & 0.59 \\
\hline 350 & B & 8 & 6 & 5 & 63 & 1.3 .4 & 7.6 & $0.33-0.83$ & 0.58 \\
\hline 350 & D & 6 & 4 & 0 & 0 & - & - & - & \\
\hline 388 & $\mathbf{A}$ & 10 & 9 & 9 & 90 & 12.2 & 8.6 & $0.33-1.0$ & 0.70 \\
\hline 388 & B & 8 & 7 & 7 & 88 & 11.6 & 8.6 & $0.38-1.0$ & 0.74 \\
\hline 388 & D & 5 & 3 & 2 & 40 & 12.5 & 4.0 & $0.17-0.46$ & 0.32 \\
\hline
\end{tabular}

\section{Statistical analyses}

Differences in fertility between thawing diluents

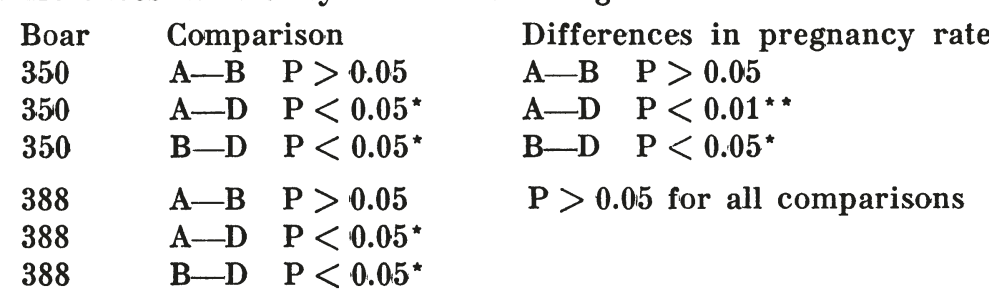

Differences in fertility between boars within thawing diluents Diluent:
A
$P>0.05$
B $\quad \mathrm{P}<0.05^{*}$
D
$P>0.05$

pregnant after insemination with spermatozoa thawed in seminal plasma had high ratios of foetuses to c. l. Thus the conclusion from the results of this trial is that no obvious differences have occurred between OLEP and seminal plasma in maintaining the fertilizing capacity of the frozen-thawed spermatozoa.

From Tables 5 and 6 it is evident that the incidence of nonpregnant gilts not returning to normal oestrus have been highest in "low fertility" groups, c.f. boar 350 diluent D trial I and boar 172 trial IIa. 
T a b l e 6. Number of normal gilts inseminated, number of gilts not returning into normal oestrus within 25 days post insemination (25d. N.R.), pregnancies and numbers of corpora lutea and of foetuses and ratios of foetuses to c.l. in pregnant gilts slaughtered four weeks after insemination in trial IIa.

\begin{tabular}{|c|c|c|c|c|c|c|c|c|c|}
\hline \multirow[t]{2}{*}{ Boar } & \multirow{2}{*}{$\begin{array}{c}\text { Thawing } \\
\text { diluent }\end{array}$} & \multicolumn{4}{|c|}{ Number of gilts } & \multicolumn{2}{|c|}{ In pregnant gilts } & \multicolumn{2}{|c|}{$\begin{array}{l}\text { Ratio of foetuses } \\
\text { to c.l. }\end{array}$} \\
\hline & & ins. & $\begin{array}{l}\text { 25d. } \\
\text { N.R. }\end{array}$ & pregn. & $\%$ & $\begin{array}{c}\text { mean } \\
\text { number } \\
\text { of } c .1 .\end{array}$ & $\begin{array}{c}\text { mean } \\
\text { number of } \\
\text { foetuses }\end{array}$ & range & mean \\
\hline 388 & A & 9 & 8 & 7 & 78 & 13.3 & 10.0 & $0.50-1.0$ & 0.75 \\
\hline 388 & C & 10 & 8 & 8 & 80 & 13.5 & 11.0 & $0.64-1.0$ & 0.81 \\
\hline 172 & $\mathbf{A}$ & 10 & 6 & 4 & 40 & 12.0 & 5.5 & $0.33-0.57$ & 0.46 \\
\hline 172 & C & 10 & 7 & 4 & 40 & 13.3 & 8.5 & $0.47-0.80$ & 0.64 \\
\hline 1164 & $\mathbf{A}$ & 10 & 3 & 2 & 20 & 13.5 & 8.0 & $0.56-0.69$ & 0.59 \\
\hline 1164 & C & 8 & 6 & 6 & 75 & 12.5 & 7.7 & $0.29-0.90$ & 0.61 \\
\hline
\end{tabular}

\section{Statistical analyses}

Differences in fertility between $\mathrm{A}$ and $\mathrm{C}$ for each boar $\mathrm{P}>0.05$ for all differences.

Differences in pregnancy rate between $A$ and $C$ within the boars, boar $388 \mathrm{P}>0.05$, boar $1164 \mathrm{P}<0.05^{\star}$.

Analyses of variance between boars in ratio of foetuses to c.l. in pregnant gilts, diluent $\mathrm{A} P<0.05^{\star}$, diluent $\mathrm{C} P>0.05$.

Differences in fertility between boars in diluent $\mathrm{C}$, $388-172 \mathrm{P}<0.05^{\star}, 388-1164, \mathrm{P}>0.05,1164-172 \mathrm{P}>0.05$.

\section{Comparison of boars on fertility of frozen-thawed spermatozoa}

The possibilities for statistical analyses of differences in fertility among the boars used are limited by the small numbers of gilts inseminated in each experimental group. The overall impression of the results is that such differences have occurred in the present investigation.

In trial $I$ the fertility of spermatozoa from boar 388 was almost significantly higher $(\mathrm{P}<0.05)$ than for boar 350 after thawing in protein free seminal plasma.

In trial IIa analyses of variance showed that after thawing in seminal plasma the ratios of foetuses to c.l. in pregnant gilts varied almost significantly $(P<0.05)$ among the boars. Following thawing in OLEP analyses of variance did not indicate any significant differences in ratios of foetuses to c.l. in pregnant gilts caused by the boars. However, when the fertility of boar 
388 was compared with that of boar 172 the difference was almosit significant $(\mathrm{P}<0.05)$.

From these results it can be concluded that differences in fertility of the frozen-thawed spermatozoa have occurred among the boars used. The differences seemed to affect pregnancy rates as well as litter sizes, i.e. ratios of foetuses to c.l. in pregnant gilts. Furthermore the differences occurred regardless of thawing diluents.

\section{DISCUSSION}

In the fertility tests performed all gilts were inseminated twice during a spontaneously occurring heat period with $6 \times 10^{9}$ spermatozoa per insemination dose. All inseminations were carried out by the same person. Trial I was to a large extent a split ejaculate trial while trial IIa was performed strictly as a split ejaculate trial. Thus the results obtained could be regarded as reliable and representative for the method used and as to the comparison of thawing diluents, although the number of gilts within each experimental group was limited.

From the results of the present investigation it is evident that thawing in seminal plasma, protein free seminal plasma and in OLEP yielded equal fertility results. Thawing in isotonic glucose solution, on the other hand, yielded low fertility.

The percentages of fertilized ova recovered in gilts slaughtered 24-48 hrs. are lower than those reported by Pursel \& Johnson $(1975 \mathrm{a}, \mathrm{b})$. However, it should be noted that in the present study the percentages of fertilized ova have been calculated on the total number of ova recovered not from gilts with fertilized ova only. Furthermore only cleaved ova have been recorded as fertilized. Regarding the time needed for cleavage of fertilized pig ova (Alanko 1974, Brinster 1974, Hunter 1974) one-cell stages of fertilized ova might have been recorded as not fertilized. This could have happened in gilts with ovulation late in oestrus who were slaughtered 24 hrs. after insemination. However these cases have most likely not affected the overall results.

In the gilits belonging to diluent groups A, B and C slaughtered four weeks after insemination the pregnancy rates and the mean numbers of foetuses in pregnant gilts closely resembled those obtained with artificial insemination with fresh boar semen in Sweden (SHS 1974). Even if some decrease in litter size were to occur from four weeks of pregnancy until parturition the litter 
sizes still would be acceptable. In gilts inseminated with spermatozoa thawed in isotonic glucose solution the pregnancy rates four weeks after insemination were very low. On the other hand in this group a comparatively high percentage of the non-pregnant gilts did not return in oestrus within 25 days after insemination. This indicates that fertilizations have occurred but the numbers of fertilized ova have not been high enough to ensure a continued pregnancy (Polge et al. 1966).

The optimum values of osmotic pressure in diluents for boar spermatozoa have been pointed out by several workers (c.f. Mann 1964, Pursel \& Johnson 1975 a). In the present study isotonic glucase solution turned out to be a less efficient thawing diluent. In a previous report Crabo et al. (1972 a) got comparably poor results when using TESNaK-glucose as thawing diluent. It could thus be concluded that, with the freezing procedure used, physiological levels of osmotic pressure and of $\mathrm{pH}$ in the thawing diluent are not enough to maintain the fertilizing ability of the frozen-thawed spermatozoa.

In seminal plasma, protein free seminal plasma and OLEP, not only $\mathrm{pH}$ and osmotic pressure, but also the amounts of $\mathrm{Na}$, $\mathrm{K}, \mathrm{Cl}$, Ca and of $\mathrm{Mg}$ are on equal levels.

The difficulty in estimating the proper time of insemination during the long heat period of sows and gilts demands that the fertilizing capacity of inseminated spermatozoa must be maintained during a comparatively long period of time and/or that inseminations are carried out twice during the oestrus period. Einarsson \& Viring (1973) showed that the number of spermatozoa persisting in the genital tract of gilts inseminated with deep frozen spermatozoa thawed in seminal plasma was higher than in gilts inseminated with spermatozoa thawed in TESNaKglucose. The in vitro-survival at $37^{\circ} \mathrm{C}$ of spermatozoa thawed in seminal plasma or in OLEP seems to be equal while spermatozoa thawed in isotonic glucose solution have a shorter time of in vitro survival (Larsson et al. 1976). Most likely there is a correlation between in vitro and in vivo survival. If so, a common effect of seminal plasma, protein free seminal plasma and OLEP would be to maintain the fertilizing capacity of the frozen-thawed spermatozoa for a sufficient time to permit fertilization within the female genital tract.

Possible causes of the favourable results following thawing in seminal plasma, protein free seminal plasma and OLEP are the 
electrolyte levels, the $\mathrm{pH}$ and the osmotic pressure common for these diluents. Graham \& Crabo (1972) stated that low ionic strength in diluted semen prepared for freezing was of importance for good survival and for minimizing enzyme leakage from the spermatozoa during the freezing-thawing procedure. In the present study this aspect was considered by a three-fold dilution with a diluent of low ionic strength before freezing. Apparently in semen prepared in this manner there is a need for a thawing diluent that can compensate for the prefreezing withdrawal of electrolytes.

Weil \& Rodenburg (1962) showed that spermatozoa are coated with proteins originating from the accessory sex glands. These coating proteins may be of importance for the fertilizing capacity of the spermatozoa (cf. Crabo \& Hunter 1975). An important function of the thawing diluent would be to preserve this protective coating. It seems probable that seminal plasma and protein free seminal plasma as well as OLEP do act in this way. The electrolyte composition of all these media are similar (Table 3).

Iritani et al. (1974) analysing uterine and oviductal secretions of oestrus sows found levels of sodium, potassium and chloride very similar to those of seminal plasma. The uterine fluids have been considered to play an important role in capacitation of mammalian spermatozoa (cf. Bedford 1970, 1974). Oliphant \& Brackett (1973) found that solution with high ionic strength, i.e. high levels of sodium in culture media, promoted in vitro capacitation of mice spermatozoa.

Considering the chemical composition of seminal plasma, protein free seminal plasma and OLEP it would be expected that they do not interfere with the biochemical environment within the female genital tract of the oestrus sow. Possibly interaction between the intrauterine secretions and the biochemical properties of the insemination doses promotes capacitation of the spermatozoa.

Brooks \& Mann (1973) found that pyruvate was preferably utilized as energy source by boar spermatozoa. Brinster stated that pyruvate was an essential substrate for all early cleavage stages of mammalian embryos. Einarsson et al. (1976) showed that molecules of different sizes inseminated via the cervix after suspension in seminal plasma enter the oviducts of oestrus gilts within $1 \mathrm{hr}$. after insemination. 
A hypothesis about the effects of seminal plasma, protein free seminal plasma and OLEP as thawing diluents could be summarized as follows: At thawing the protective protein coat of the spermatozoa is maintained. After thawing the diluents provide enough available energy and a favourable electrolyte balance for sufficient survival of the spermatozoa. The thawing diluents do not interfere with the biochemical environment within the genital tract of the oestrus sow. Possibly interaction between the intrauterine secretions and the components of the diluents promotes capacitation of the spermatozoa. Pyruvate originating from OLEP and similar substances probably present in seminal plasma might be of importance for the embryonic development following conception.

In a brief communication preceding the present report (Larsson \& Einarsson 1975 b) differences in fertility following insemination with frozen-thawed spermatozoa from different boars were indicated. From the results of the present investigation it is evident that such differences exist and that they affect pregnancy rate as well as ratio of foetuses to c.l. in pregnant gilts. There also appears to be boars with lower fertility of their frozen-thawed spermatozoa than those used in the present investigation although their fertility with fresh semen was good (Larsson \& Einarsson 1976). The differences between boars occurred independent of thawing diluent. It therefore seems probable that the differences between boars were related to different resistance of the spermatozoa to freezing and thawing.

The frequency of boars with low freezability of their spermatozoa, but with a normal semen quality, is so far unknown. The establishment of selection criteria for good freezability other than fertility tests seems to be of great importance. Such work is in progress (Larsson \& Einarsson 1976).

\section{REFERENCES}

Alanko, M.: Fertilization and early development of ova in A.I.-gilts, with special reference to the role of tubal sperm concentration. A clinical and experimental study. Thesis. Helsinki 1974, 90 pp.

Bane, A.: Acrosomal abnormality associated with sterility in boar. Proc. IV Int. Congr. Anim. Reprod., The Hague 1961, 4, 810-817.

Bedford, J. M.: Sperm capacitation and fertilization in mammals. Biol. Reprod. 1970, Suppl. 2, 128-158. 
Bedford, J. M.: Maturation of the fertilization ability of mammalian spermatozoa in the male and female reproductive tract. Biol. Reprod. 1974, 11, 346-362.

Boehnke, H. J., R. Hahn, K. H. Hillman, H. Treu, W. Lorrmann \& H. F. Zoder: Zur Tiefgefrierung von Ebersperma. 3. Mitteilung: Weitere Labor- und Besamungsversuche unter Verwendung von TEST und TESNaK-Verdünner sowie verschiedenen Auftanmethoden. (3. Communication: Deepfreezing of boar semen; Laboratory experiments and further field trials using TEST and TESNaK-diluent and different thawing methods). Dtsch. tierärztl. Wschr. 1974, 81, 336-339.

Brinster, R. L.: Embryo development. J. Animal Sci. 1974, 38, 10031012.

Brooks, D. E. \& T. Mann: Pyruvate metabolism in boar spermatozoa. J. Reprod. Fertil. 1973, 34, 105-119.

Crabo, B. \& S. Einarsson: Fertility of deep frozen boar spermatozoa. Acta vet. scand. 1971, 12, 125-127.

Crabo, B. G. \& A. G. Hunter: Sperm maturation and epididymal function. In Control of Male Fertility. ed. J. J. Sciana, C. Markland, J. J. Speidel. Harper \& Row, Publishers, Hagerstown, Maryland $1975,2-23$.

Crabo, B., S. Einarsson, A.-M. Lamm, O. Soosalu \& S. Viring: Studies on the fertility of deep frozen boar spermatozoa. VII Int. Congr. Anim. Reprod., Munich 1972 a, II, 1647-1652.

Crabo, B., K. I. Brown \& E. F. Graham: Effect of some buffers on storage and freezing of boar spermatozoa. J. Animal Sci. 1972 b, $35,377-382$.

Einarsson, S.: Studies on the composition of epididymal content and semen in the boar. Acta vet. scand. 1971, Suppl. 36.

Einarsson, S. \& S. Viring: Distribution of frozen-thawed spermatozoa in the reproductive tract of gilts at different time intervals after insemination. J. Reprod. Fertil. 1973, 32, 117-120.

Einarsson, S., O. Soosalu, T. Swensson \& S. Viring: On the fertility and survival of deep frozen boar spermatozoa thawed in skim milk. Acta vet. scand. $1972,13,446-448$.

Einarsson, S., T. Swensson \& S. Viring: A field trial on the fertility of deep frozen boar spermatozoa. Nord. Vet.-Med. 1973, 25, 372376.

Einarsson, S., M. Holtman, O. Soosalu, T. Swensson \& S. Viring: Studies on the fertility and survival of deep-frozen boar spermatozoa thawed in four different diluents. Zuchthygiene 1974, 9, 40-45.

Einarsson, S., B. Jones, K. Larsson \& S. Viring: Unpubl. results 1976.

Graham, E. F. \& B. G. Crabo: Some factors influencing the freezing of boar spermatozoa. VII Int. Congr. Anim. Reprod., Munich 1972, II, 1627-1632.

Graham, E. F., A. H. J. Rajamannan, M. K. L. Schmehl, M. Maki-Laurila \& R. E. Bower: Preliminary report on procedure and rationale for freezing boar semen. A.I. Dig. 1971a, 19, no. 1, 12-14. 
Graham, E. F., A. H. J. Rajamannan, M. K. L. Schmehl, M. Maki-Laurila \& R. E. Bower: Fertility studies with frozen boar spermatozoa. A.I. Dig. $1971 b, 19$, no. $6,6-8$.

Holst, S. J.: Sterility in boars. Nord. Vet.-Med. 1949, 1, 87-120.

Hunter, R. H. F.: Chronological and cytological details of fertilization and early embryonic development in the domestic pig, Sus scrofa. Anat. Rec. 1974, 178, 169-186.

Iritani, A., E. Sato \& Y. Nishikawa: Secretion rates and chemical composition of oviduct and uterine fluids in sows. J. Animal Sci. $1974,39,582-588$.

Larsson, $K . \& S$. Einarsson: Fertility and post-thawing characteristics of deep frozen boar spermatozoa. Andrologia 1975a, 7, 25-30.

Larsson, $K$. \& S. Einarsson: A new thawing fluid for deep frozen boar spermatozoa. Acta vet. scand. $1975 \mathrm{~b}, 16,143-145$.

Larsson, $K$. \& S. Einarsson: Influence of boars on the relationship between fertility and post thawing sperm quality of deep frozen boar spermatozoa. Acta vet. scand. 1976, 17, 74-82.

Larsson, $K$., S. Einarsson \& L. Nicander: Influence of thawing diluents on vitality, acrosome morphology, ultrastructure, enzyme release and fertility of deep frozen boar spermatozoa. Acta vet. scand. 1976, 17, 83-100.

Lindström, B.: Kompendium i medicinsk statistik. (Compendium in medical statistics). Stockholm 1975.

Mann, T.: The biochemistry of semen and of the male reproductive tract. Methuen, London 1964.

Melrose, D. R. \& C. O'Hagan: Investigations into the techniques of insemination in the pig. Proc. IV Int. Congr. Anim. Reprod., The Hague 1961, IV, 855-859.

Nagase, H. \& T. Niwa: Deep freezing bull semen in concentrated pellet form. Proc. V Int. Congr. Anim. Reprod., Trento 1964, III, 410415.

Oliphant, G. \& B. G. Brackett: Capacitation of mouse spermatozoa in media with elevated ionic strength and reversible decapacitation with epididymal extracts. Fertil. and Steril. 1973, 24, 948955.

Paquignon, M. \& F. du Mesnil du Buisson: Fertilité et prolificité de truies inséminées avec du sperme congelé comparaison de deux dileurs. Résultats préliminaires. (Fertility and prolificacy of sows inseminated with frozen semen, comparison between two diluents. Preliminary results). Journées de Recherche Porcine en France 1973, 356-357.

Polge, C., L. E. A. Rowson \& M. C. Chang: The effect of reducing the number of embryos during early stages of gestation on the maintenance of pregnancy in the pig. J. Reprod. Fertil. 1966, $12,395-397$.

Pursel, V. G. \& L. A. Johnson: Fertility with frozen boar spermatozoa. J. Animal Sci. 1971a, 33, 265.

Pursel, V. G. \& L. A. Johnson: Fertilizing capacity of frozen boar spermatozoa. J. Animal Sci. 1971b, 33, 1162. 
Pursel, V. G. \& L. A. Johnson: Frozen boar spermatozoa: Methods of thawing. J. Animal Sci. 1974, 39, 222.

Pursel, V. G. \& L. A. Johnson: Freezing of boar spermatozoa: Fertilizing capacity with concentrated semen and a new thawing procedure. J. Animal Sci. 1975a, 40, 99-102.

Pursel, V. G. \& L. A. Johnson: Effect of time of insemination on fertilizing capacity of frozen boar spermatozoa. J. Animal Sci. $1975 \mathrm{~b}, 41,375$.

Richter, L. \& A. Liedicke: Ein Verfahren zum Tiefgefrieren von Ebersperma. (Method of deep freezing boar semen). VII Int. Congr. Anim. Reprod., Munich 1972, II, 1617-1621.

Richter, L., E. Romeny, K. F. Weitze \& F. Zimmermann: Zur Tiefgefrierung von Ebersperma. VII. Mitteilung: Weitere Labor- und Besamungsversuche mit dem Verdünner Hülsenberg VIII. (Deep freezing of boar semen. 7th Communication: Laboratory and field experiments using the extender Hülsenberg VIII). Dtsch. tierärztl. Wschr. 1975, 82, 155-162.

Romeny, E.: Untersuchungen zur Tiefgefrierkonservierung von Ebersamen mit den Hülsenberger Verfahren. (Investigations on deep freezing of boar semen with the Hülsenberg method). Thesis. Hannover 1974, $84 \mathrm{pp}$.

Romeny, E., K. H. Hillmann \& L. Richter: Zur Tiefgefrierung von Ebersamen. 4. Mitteilung: Labor- und Besamungsversuche mit dem Hülsenberg Verdünner IV. (Deep freezing of boar semen. 4th Communication: Laboratory experiments and inseminations with frozen boar semen using the extender Hülsenberg IV). Dtsch. tierärztl. Wschr. 1974, 81, 353-354.

SHS: Svensk Husdjursskötsel ek. förening, åreredogörelse. (Swedish national association for livestock breeding and production). Annual report 1974.

Snedecor, G. W.: Statistical Methods. Ames, Iowa 1966, 5th Ed.

Weil, A.J. \& J.M. Rodenburg: The seminal vesicle as the source of the spermatozoa-coating antigen of seminal plasma. Proc. Soc. exp. Biol. (N.Y.) 1962, 109, 567-570.

Westendorf, P., L. Richter \& H. Treu: Zur Tiefgefrierung von Ebersperma: Labor- und Besamungsergebnisse mit dem Hülsenberger Paillette-Verfahren. (Deep frezing of boar semen. Laboratory findings and insemination results with the Hülsenberger Pailletten technique). Dtsch. tierärztl. Wschr. 1975, 82, 261-267.

\section{SAMMANFATTNING}

Fertilitet med djupfryst galtsperma. Inverkan av tiningsmedier och av gallar.

I detta arbete redovisas fertilitetsresultaten från två inseminationsförsök med djupfryst galtsperma. Avsikten med försöken var dels att studera effekten av olika tiningsmedier och dels att jämföra fruktsamheten av djupfrysta spermier från fyra olika galtar. Försöken omfattar totalt 139 gyltor. 
De använda tiningsmedierna har varit spermaplasma från galt, proteinfri spermaplasma, tiningsvätskan OLEP samt isoton glykoslösning. OLEP komponerades på grundval av några av spermaplasmans fysikaliska och biokemiska egenskaper. Osmotiskt tryck, $\mathrm{pH}$ och elektrolytsammansättning hos OLEP är likvärdiga med spermaplasmans motsvarande egenskaper.

Effekten av tiningsvätskorna har undersökts i split-ejakulat försök och observerade skillnader kan helt hänföras till respektive upptiningsmedium.

Resultaten visar att upptining i spermaplasma, proteinfri spermaplasma och i OLEP har givit likvärdiga resultat. Upptining i isoton glykoslösning har givit signifikant sämre resultat vad avser andel befruktade ägg 24-48 timmar efter insemination. Vidare var fertiliteten 4 veckor efter insemination nästan signifikant lägre för gyltor inseminerade med spermier upptinade $i$ isoton glykoslösning.

Möjliga verkningsmekanismer för de olika tiningsvätskorna diskuteras. Elektrolytsammansättning, $\mathrm{pH}$ och osmotiskt tryck i tiningsmediet synes med tillämpad djupfrysningsmetod vara av betydelse för de upptinade spermiernas överlevnad och befruktningsförmåga.

Nästan signifikanta skillnader i fertilitet konstaterades mellan sperma från olika galtar. Dessa skillnader berörde såväl dräktighetsprocent som kullstorlek. Skillnaderna förelåg oberoende av om upptining skett i spermaplasma eller i OLEP. Variationsorsaken synes vara varierande resistens hos spermierna under djupfrysning/upptining. Behovet av laboratoriemetoder för utvärdering av spermier från olika galtar poängteras.

(Received November 24, 1975).

Reprints may be requested from: K. Larsson, the Department of Obstetrics and Gynaecology, Veterinary College, S-104 05 Stockholm 50, Sweden. 